\title{
Soil compaction due to forest harvest operations
}

\author{
Moacir de Souza Dias Junior ${ }^{(1)}$, Sebastião da Fonseca( ${ }^{(2)}$, Cezar Francisco Araújo Júnior ${ }^{(1)}$ \\ and Arystides Resende Silva(1)
}

\begin{abstract}
(1)Universidade Federal de Lavras, Dep. de Ciência do Solo, Caixa Postal 3037, CEP 37200-000 Lavras, MG, Brazil. E-mail: msouzadj@ufla.br, cfaj@bol.com.br, arystidesrs@yahoo.com.br ${ }^{(2)}$ Aracruz Celulose S.A., Caixa Postal 331.011, CEP 29197-000 Aracruz, ES, Brazil. E-mail: sf@aracruz.com.br
\end{abstract}

\begin{abstract}
The objective of this work was to determine, through the use of the bearing capacity model, the traffic effects of the forest harvest operations on the preconsolidation pressure $\left(\sigma_{\mathrm{p}}\right)$, during one cycle of the eucalyptus plantation. The work was conducted using undisturbed soil samples, collected at the surface of the A horizon and in the top of the B horizon of an Udult (PA), Aquox (FX) and Udox (LA) soils. The undisturbed soil samples were used in the uniaxial compression tests. The soil sampling was done before and after the harvest operations. The operations performed with the Forwarder caused greater soil compaction than the ones done with the Feller Büncher and Harvester. The percentage of soil samples, in the region with additional soil compaction, indicated that the Udult was the soil class more susceptible to soil compaction, followed by the Aquox and Udox. Despite Udult is the more susceptible to soil compaction, the regeneration of the soil structure in this soil class was more efficient than in Aquox. The percentage of soil samples with $\sigma_{\mathrm{p}}$ values in the region with additional soil compaction in 1996, 1998 and 2004, after harvest operations, indicated a sustainable forest exploration in this period.
\end{abstract}

Index terms: Eucalyptus, soil structure, preconsolidation pressure, bearing, capacity model.

\section{Compactação do solo em conseqüência das operações de colheita florestal}

Resumo - O objetivo deste trabalho foi determinar, pelo uso do modelo de capacidade de suporte de carga, o efeito do tráfego das operações de colheita florestal na pressão de preconsolidação $\left(\sigma_{\mathrm{p}}\right)$, durante um ciclo do eucaliptus. O trabalho foi realizado com amostras indeformadas, coletadas na superfície do horizonte A e no topo do horizonte B de um Argissolo Amarelo, de um Plintossolo e de um Latossolo Amarelo. As amostras indeformadas foram usadas nos ensaios de compressão uniaxial. A amostragem foi realizada antes e depois das operações de colheita. As operações realizadas com o Forwarder causaram maior compactação do solo do que as operações realizadas com o Feller Büncher e o Harvester. A porcentagem de amostras de solo, na região onde ocorre compactação adicional, indicou que o Argissolo Amarelo foi mais suscetível à compactação, seguido do Plintossolo e do Latossolo Amarelo. Apesar de o Argissolo Amarelo ser a classe de solo mais suscetível à compactação, a regeneração da estrutura nesta classe de solos foi mais evidente do que no Plintossolo. As porcentagens de amostras de solo com $\sigma_{p}$ situados na região em que ocorreu compactação adicional em 1996, 1998 e 2004, após as operações de colheita, indicaram uma exploração sustentável da floresta nesse período.

Termos para indexação: Eucalyptus, estrutura do solo, pressão de preconsolidação, modelos, capacidade de suporte de carga.

\section{Introduction}

In the modern forestry industry there is a concern about the sustainability and longevity of the exploration system. This is justified by the fact that the machinery used for harvest is becoming heavier and more powerful (Horn et al., 2004; Dias Junior et al., 2005), which may cause long-term reductions in forestry productivity. There is also a concern about the natu- ral recovery of soil structure in areas cultivated with eucalyptus, due to the harvest cycle for cellulose (Dias Junior, 2003). Reductions in the preconsolidation pressure values have been associated with this concern (Dias Junior et al., 2005), however there are few studies considering this hypothesis in the literature.

The main source of forest soil structure degradation is soil compaction resulted of machinery traffic in harvest operations, in the whole area or at a specific site 
(Dias Junior et al., 2005). In both cases, soil susceptibility to compaction increases as the soil becomes wetter (Arvidsson et al., 2003; Barbosa et al., 2005; Silva et al., 2006), or when harvest operations are conducted with heavier and more powerful machines (Horn et al., 2004) operating repeatedly (Raper, 2005) through the eucalyptus cycles. Sustainable forest development is related to the traffic of machinery used in the harvest operations (Dias Junior et al., 2003, 2005). The scheduling of this traffic would contribute to minimize soil compaction, and consequently, the losses of productivity (Dias Junior et al., 2005). Thus, it is important to determine the soil bearing capacity as a function of soil moisture, and to quantify the damages caused to soil structure, when applied pressures exceed the soil bearing capacity (Dias Junior \& Pierce, 1996; Oliveira et al., 2003; Silva et al., 2003).

Another concern of the forest industry is that harvest operations are performed during the whole year in dry and rainy seasons (Dias Junior et al., 2003). Researchers have showed that the risk of compaction is likely to occur in soils with high moisture content, under tracks of heavy vehicles with high loads (Dias Junior et al., 1999; Raper, 2005). A solution for this problem would be a controlled traffic (Horn et al., 2004) to maintain the more favorable area for plant growth by restricting soil compaction to traffic lanes (Braunack et al., 1995).

In order to minimize risk of additional soil compaction (Dias Junior, 2000), the traffic should be performed considering soil bearing capacity (Dias Junior et al., 2005). Besides, determining the changes in the soil bearing capacity with changes in water content (Kondo \& Dias Junior, 1999) would help to schedule farm trafficking and cultivation operations at the appropriate moisture content (Hamza \& Anderson, 2005).

Considering that the preconsolidation pressure is an indicator of the soil bearing capacity (Dias Junior et al., 2005; Silva et al., 2006) and of the maximum pressure that should be applied to a soil, in order to avoid soil compaction (Defossez \& Richard, 2002; Barbosa et al., 2003), the objective of this study was to determine, through the use of the bearing capacity model, the traffic effects of forest harvest operations on the preconsolidation pressure $\left(\sigma_{\mathrm{p}}\right)$ during one cycle of the eucalyptus plantation.

\section{Material and Methods}

This work was carried out in experimental areas of Aracruz Celulose S.A., cultivated with eucalyptus, in
Aracruz County, at $40^{\circ} 14^{\prime} \mathrm{W}, 19^{\circ} 51^{\prime} \mathrm{S}$, Espírito Santo State, Brazil. The soils were classified as Argissolo Amarelo (PA), Plintossolo (FX) and Latossolo Amarelo (LA) (Embrapa, 1999) or Udult (PA), Aquox (FX) and Udox (LA) (Soil..., 1999). The experimental area was equal to approximately 22,21 , and 2 ha in the Udult, Aquox and Udox, respectively. These areas were at the end of the third cultivation cycle with eucalyptus, planted in 1997 in the Udult using digging, and in 1996 and 1998 using coppice systems in the Aquox and Udox, respectively. The particle size distribution and the textural classes are presented in Table 1.

The machines used in the forest harvest operations were: Feller Büncher, model CAT-312, Caterpillar, with tracks, weight without load 12,000 kg; Harvester, model FH200, Fiatallis, with tracks, weight without load $20,000 \mathrm{~kg}$; and Forwarder with 6 tires, model RK-610, Randon, weight without load $13,750 \mathrm{~kg}$, and weight with load $23,750 \mathrm{~kg}$.

The soil sampling consisted of two stages: before and after harvest operations.

\section{Before harvest operations}

To obtain the bearing capacity model which is the relationship between preconsolidation pressure and moisture content, 27 undisturbed soil samples (9 undisturbed soil samples x 3 replications) of $0.064 \mathrm{~m}$ diameter and $0.0254 \mathrm{~m}$ height were collected randomly, at $0-0.03 \mathrm{~m}$ (surface of the A horizon), in the Udult, Aquox and Udox, and at $0.35-0.38 \mathrm{~m}$ in the Udult and Aquox, and at $0.15-0.18 \mathrm{~m}$ in the Udox (top of the B horizon). These soil samples were collected in 1996 in the Udult and Aquox, and in 1998 in the Udox.

Samples were initially saturated in a tray with water up to $2 / 3$ of the sample height, for 24 hours, and were air-dried in laboratory until the moisture content was in the range of 0.04 to $0.32 \mathrm{~kg} \mathrm{~kg}^{-1}$, and then used in the uniaxial compression test (Bowles, 1986).

For the uniaxial compression tests, the undisturbed soil samples were kept within the coring cylinders, which

Table 1. Particle size distribution and textural classes of the Udult, Aquox and Udox soils ${ }^{(1)}$.

\begin{tabular}{|c|c|c|c|c|c|}
\hline \multirow[t]{2}{*}{ Soil class } & Depth & Clay & Silt & Sand & Soil textural class \\
\hline & $(\mathrm{m})$ & \multicolumn{4}{|c|}{------- $\left(\mathrm{g} \mathrm{kg}^{-1}\right)$------- } \\
\hline \multirow[t]{2}{*}{ Udult } & $0-0.03$ & 190 & 87 & 723 & Sandy loam \\
\hline & $0.35-0.38$ & 240 & 111 & 649 & Sandy clay loam \\
\hline \multirow[t]{2}{*}{ Aquox } & $0-0.03$ & 130 & 75 & 795 & Sandy loam \\
\hline & $0.35-0.38$ & 200 & 99 & 701 & Sandy clay loam \\
\hline \multirow[t]{2}{*}{ Udox } & $0-0.03$ & 200 & 70 & 730 & Sandy clay loam \\
\hline & $0.15-0.18$ & 220 & 60 & 720 & Sandy clay loam \\
\hline
\end{tabular}

${ }^{(1)}$ Average of three replications. 
were placed into the compression cell and, subsequently, subjected to pressures $25,50,100,200,400,800$ and $1,600 \mathrm{kPa}$.

Each pressure was applied until $90 \%$ of the maximum deformation was reached, and then the pressure was increased to the next level. The $90 \%$ of maximum deformation was determined by drawing a straight line through the data points, in the initial part of the curve obtained when dial readings were plotted versus square root of the time, until this line intercepted the y axis (dial readings). A second straight line was drawn from this intersection with all abscissas 1.15 times as large as corresponding values on the first line. The intersection of this second line and the laboratory curve is the point corresponding to $90 \%$ consolidation (Taylor, 1948; Holtz $\&$ Kovacs, 1981). From the soil compression curves, the preconsolidation pressures $\left(\sigma_{\mathrm{p}}\right)$ were determined as a function of the moisture content (U) (Dias Junior \& Pierce, 1995). Regression analyses were accomplished using the software Sigma Plot (Jandel Scientific) to obtain the bearing capacity model, which is the adjustment of $\sigma_{\mathrm{p}}$ as a function of $\mathrm{U}$ (Dias Junior et al., 2005).

\section{After harvest operations}

To determine which harvest operation caused more soil compaction, 27 undisturbed soil samples (9 undisturbed soil samples $\mathrm{x} 3$ replications), of the same size, and in the same depths as described before, were collected in 1996 in the traffic line of the Feller, Harvester and Forwarder in the Udult and Aquox.

Dias Junior et al. (1999) identified as the operation that caused more soil compaction, in 1996, the one performed with the Forwarder. Due to that, 27 undisturbed soil samples (9 undisturbed soil samples $\mathrm{x} 3$ replications) were collected only in the traffic line of the Forwarder, in 1998, 2000, 2002, and 2004 in the Udult,
Aquox and Udox, in order to verify the natural alleviation of the soil compaction through the time.

These undisturbed soil samples were submitted to the uniaxial compression test, as mentioned previously (Bowles, 1986), with moisture content at which the soil samples were collected (Table 2). The undisturbed soil samples were involved in plastic, covered with paraffin and stored at room temperature. After completion of the uniaxial compression test, $\sigma_{\mathrm{p}}$ and moisture content were obtained according to Dias Junior \& Pierce (1995) and Gardner (1986), respectively.

In order to analyze the traffic effect of the harvest operations on the preconsolidation pressure of Udult, Aquox and Udox, during one eucalyptus cycle, the bearing capacity models were divided into three regions (Dias Junior et al., 2005). Regions considered (Figure 1) were: a) the one where preconsolidation pressure values, determined after the traffic, surpassed the higher limit of the confidence interval, being considered as the region with additional soil compaction; b) the one where preconsolidation pressures, determined after the traffic, were within the limits of confidence intervals (although soil samples did not suffer soil compaction, this region indicates the soil samples that could suffer soil compaction in the next harvest operations, if the applied pressures are larger than the higher limit of the confidence interval); and c) a region where the preconsolidation pressure values, determined after the traffic, were below the lower limit of the confidence interval.

According to Dias Junior (2003) and Dias Junior et al. (2005), a natural recovery of the soil structure will be indicated by a decrease in the percentage of soil samples in region a, or an increase in the percentage of soil samples in regions b and c (Figure 1).

Table 2. Moisture content $\left(\mathrm{kg} \mathrm{kg}^{-1}\right)$ at which soil samples were collected in the Udult and in the Aquox, at $0-0.03$ and $0.35-0.38 \mathrm{~m}$ depths, and in the Udox at 0-0.03 and 0.15-0.18 $\mathrm{m}$ depths, after the harvest operations ${ }^{(1)}$.

\begin{tabular}{|c|c|c|c|c|c|c|c|c|}
\hline \multirow[t]{3}{*}{ Depth (m) } & \multicolumn{8}{|c|}{ Traffic line } \\
\hline & \multirow{2}{*}{$\begin{array}{c}\text { Feller } \\
1996\end{array}$} & \multirow{2}{*}{$\begin{array}{c}\text { Harvester } \\
1996\end{array}$} & \multicolumn{6}{|c|}{ Forwarder } \\
\hline & & & 1996 & 1998 & 2000 & 2002 & 2004 (before harvest) & 2004 (after harvest \\
\hline & \multicolumn{8}{|c|}{ Udult } \\
\hline $0-0.03$ & 0.1076 & 0.1328 & 0.1332 & 0.1073 & 0.1110 & 0.1486 & 0.1280 & 0.1378 \\
\hline \multirow[t]{2}{*}{$0.35-0.38$} & 0.1268 & 0.1444 & 0.1427 & 0.1107 & 0.1227 & 0.1479 & 0.1382 & 0.1437 \\
\hline & \multicolumn{8}{|c|}{ Aquox } \\
\hline $0-0.03$ & 0.1115 & 0.1268 & 0.1437 & 0.1218 & 0.1271 & 0.1325 & 0.1252 & 0.1398 \\
\hline \multirow[t]{2}{*}{$0.35-0.38$} & 0.1317 & 0.1423 & 0.1464 & 0.1300 & 0.1350 & 0.1368 & 0.1392 & 0.1452 \\
\hline & \multicolumn{8}{|c|}{ Udox } \\
\hline $0-0.03$ & $-(2)$ & - & - & 0.1098 & 0.0970 & 0.1127 & 0.1313 & 0.1475 \\
\hline $0.15-0.18$ & - & - & - & 0.1129 & 0.1038 & 0.1131 & 0.1287 & 0.1357 \\
\hline
\end{tabular}

${ }^{(1)}$ Average of 27 replications. ${ }^{(2)}$ Not determined. 
The results of the bulk density were submitted to the variance analysis, according to the completely randomized design, and the averages comparisons were made using the test of Scott-Knott $(\mathrm{p}<0,01)$. Comparisons of the bearing capacity models were made using the procedure described in Snedecor \& Cochran (1989).

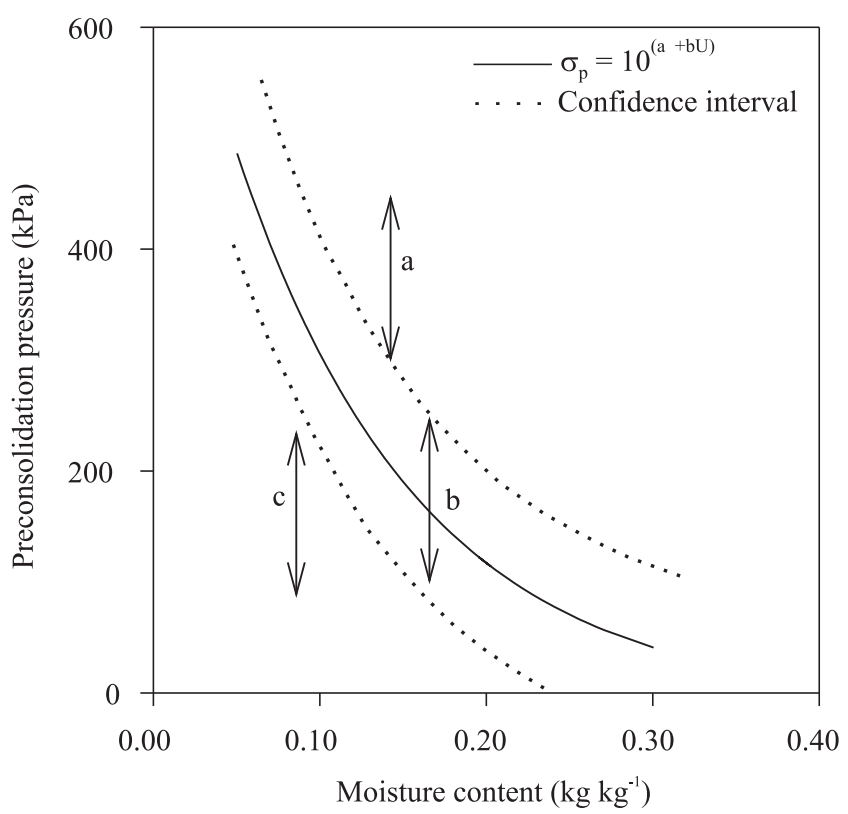

Figure 1. Criteria used to analyze the effect of harvest operations on the preconsolidation pressure of the Udult, Aquox and Udox. a) Region with additional soil compaction; b) region with no soil compaction (this region indicates the soil samples which could suffer soil compaction in the next harvest operations, if applied pressures are larger than the higher limit of the confidence interval); and c) region with no soil compaction.

\section{Results and Discussion}

The harvest operations performed with the Forwarder, in 1996, caused larger increase in the soil bulk density values than the operations with Feller Büncher and Harvester, in the same year, at $0-0.03 \mathrm{~m}$ depth in the Udult and Aquox. At $0.35-0.38 \mathrm{~m}$ depth, the bulk density values determined after the operation with the Harvester and Forwarder were the same, but larger than those for the Feller (Table 3). For the Udox, the bulk density values determined after the Forwarder operation, in 1998, were greater than the ones determined before traffic in both depths. Thus, operations with the Forwarder were those that caused more soil compaction, as indicated by an increase in the bulk density values in both depths, compared to the values determined before traffic (Dias Junior et al., 1999).

Although bulk density values determined in 1996 and 1998, after Forwarder operation, were higher in the A and B horizons of the Udult, Aquox and Udox, in 2004, before the harvest operations, they reached the same values as in 1996 and 1998 before traffic, except for the B horizon of the Udox. However, the harvest operations made in 2004 caused, again, an increase in the bulk density values, determined after harvest, compared to the values measured in 1996 and 1998 before traffic (Table 3).

The bearing capacity model obtained for the Udult, Aquox and Udox comprised type $\sigma_{\mathrm{p}}=10^{(\mathrm{a}+\mathrm{bU})}$, with significant $\mathrm{R}^{2}$ at the level $1 \%$, that varied from 0.91 to 0.94 . The estimated $a$ and $b$ values varied from 2.79 to 3.04 , and from -3.45 to -5.54 , respectively (Table 4). The type of these equations was the same as those of Dias Junior \& Pierce (1996).

The homogeneity tests of the equations (Snedecor \& Cochran, 1989) indicated that the A horizon equations were homogeneous and the B horizon equations

Table 3. Bulk density $\left(\mathrm{Mg} \mathrm{m}^{-3}\right)$ determined before and after harvest operations in the Udult and in the Aquox, at $0-0.03$ and $0.35-0.38 \mathrm{~m}$ depths, and in the Udox at $0-0.03$ and $0.15-0.18 \mathrm{~cm}$ depths ${ }^{(1)}$.

\begin{tabular}{|c|c|c|c|c|c|c|c|c|c|}
\hline \multirow[t]{3}{*}{ Depth (m) } & \multirow{3}{*}{$\begin{array}{l}\text { Before traffic } \\
\quad(1996)^{(2)}\end{array}$} & \multicolumn{8}{|c|}{ Traffic line } \\
\hline & & \multirow{2}{*}{$\begin{array}{c}\text { Feller } \\
1996 \\
\end{array}$} & \multirow{2}{*}{$\begin{array}{c}\text { Harvester } \\
1996 \\
\end{array}$} & \multicolumn{6}{|c|}{ Forwarder } \\
\hline & & & & 1996 & 1998 & 2000 & 2002 & 2004 (before harvest) & 2004 (after harvest) \\
\hline & \multicolumn{9}{|c|}{ 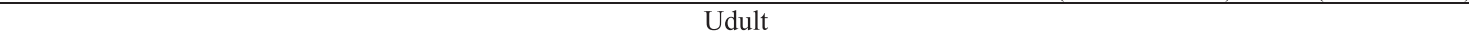 } \\
\hline $0-0.03$ & $1.31 \mathrm{a}$ & $1.36 \mathrm{a}$ & $1.50 \mathrm{c}$ & $1.56 \mathrm{~d}$ & $1.37 \mathrm{a}$ & $1.43 b$ & $1.45 b$ & $1.35 \mathrm{a}$ & $1.51 \mathrm{c}$ \\
\hline \multirow[t]{2}{*}{$\underline{0.35-0.38}$} & $1.50 \mathrm{a}$ & $1.52 \mathrm{a}$ & $1.55 \mathrm{~b}$ & $1.56 \mathrm{~b}$ & $1.46 \mathrm{a}$ & $1.51 \mathrm{a}$ & $1.52 \mathrm{a}$ & $1.49 \mathrm{a}$ & $1.52 \mathrm{a}$ \\
\hline & \multicolumn{9}{|c|}{ Aquox } \\
\hline $0-0.03$ & $1.30 \mathrm{a}$ & $1.32 \mathrm{a}$ & $1.41 b$ & $1.51 \mathrm{c}$ & $1.35 \mathrm{a}$ & $1.34 \mathrm{a}$ & $1.32 \mathrm{a}$ & $1.30 \mathrm{a}$ & $1.42 \mathrm{~b}$ \\
\hline \multirow[t]{2}{*}{$0.35-0.38$} & $1.41 \mathrm{a}$ & $1.44 \mathrm{a}$ & $1.46 \mathrm{~b}$ & $1.50 \mathrm{~b}$ & $1.44 \mathrm{~b}$ & $1.42 \mathrm{a}$ & $1.43 \mathrm{a}$ & $1.39 \mathrm{a}$ & $1.45 \mathrm{~b}$ \\
\hline & \multicolumn{9}{|c|}{ Udox } \\
\hline $0-0.03$ & $1.36 \mathrm{a}$ & $-(3)$ & - & - & $1.67 \mathrm{c}$ & $1.54 \mathrm{~b}$ & $1.52 \mathrm{~b}$ & $1.50 \mathrm{a}$ & $1.65 \mathrm{c}$ \\
\hline $0.15-0.18$ & $1.50 \mathrm{a}$ & - & - & - & $1.69 \mathrm{c}$ & $1.63 \mathrm{~b}$ & $1.61 \mathrm{~b}$ & $1.63 \mathrm{~b}$ & $1.64 \mathrm{~b}$ \\
\hline
\end{tabular}

${ }^{(1)}$ Average of 27 replications; averages followed by equal letters, in the line, were not different at $1 \%$ probability level, by the Scott-Knott test. (2)For the Udox, the condition before traffic was of 1998. ${ }^{(3)}$ Not determined. 
were not homogeneous (Table 4). For the homogeneous data, a new equation was adjusted for all $\left(\mathrm{U}, \sigma_{\mathrm{p}}\right)$, and only one equation of $\sigma_{\mathrm{p}}$ was obtained as a function of $\mathrm{U}$ (Table 4). Final equations are shown in Figures 2

Table 4. Parameters of the bearing capacity model $\left(\sigma_{p}=10^{(a+b U)}\right)$, with its respective determination coefficients $\left(\mathrm{R}^{2}\right)$, and number of undisturbed soil samples (n), collected at $0-0.03 \mathrm{~m}$ (surface of the A horizon) and $0.35-0.38 \mathrm{~m}$ (top of the $\mathrm{B}$ horizon) depths in the Udult (PA) and in the Aquox (FX), and at $0-0.03 \mathrm{~m}$ (surface of the A horizon) and $0.15-0.18 \mathrm{~m}$ (top of B horizon) depths in the Udox (LA), before harvest operations, and comparison of those models (F) according to Snedecor \& Cochran (1989).

\begin{tabular}{lccccc}
\hline Soil class & $\mathrm{a}$ & $\mathrm{b}$ & $\mathrm{R}^{2}$ & $\mathrm{n}$ & $\mathrm{F}$ \\
\hline PA & 3.04 & -5.54 & $0.91^{* *}$ & 25 & \\
FX & 2.90 & -3.67 & $0.92^{* *}$ & 26 & \\
LA & 2.79 & -3.45 & $0.94^{* *}$ & 25 & Homogeneous \\
PA x FX & & & & & Homogeneous \\
PA x LA & & & & & Homogeneous \\
FX x LA & 2.88 & -3.95 & $0.86^{* *}$ & 76 & \\
PA x FX x LA & \multicolumn{5}{c}{ Top of the B horizon } \\
PA & 2.99 & -3.44 & $0.80^{* *}$ & 27 & \\
FX & 3.42 & -6.84 & $0.87^{* *}$ & 25 & \\
LA & 2.77 & -2.68 & $0.92^{* *}$ & 24 & \\
PA x FX & \multicolumn{5}{c}{ Nonhomogeneous } \\
PA x LA & \multicolumn{5}{c}{ Nonhomogeneous } \\
FX x LA & \multicolumn{7}{c}{ Nonhomogeneous } \\
\hline
\end{tabular}

**Significant at $1 \%$ probability level.

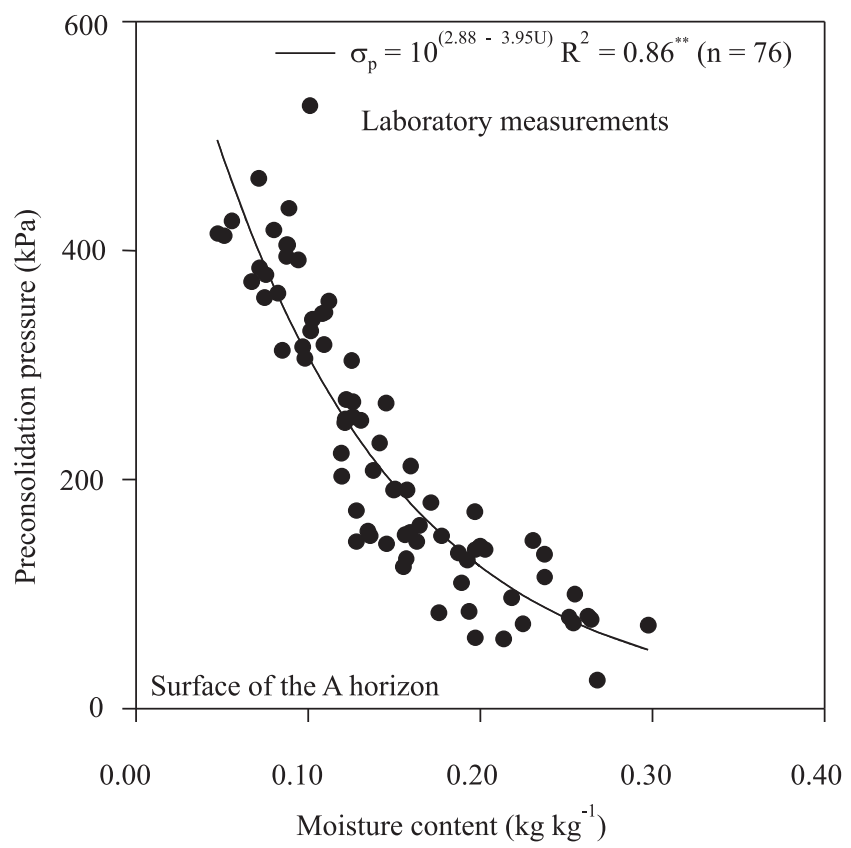

Figure 2. Bearing capacity model of the Udult, Aquox and Udox, under eucalyptus plantation at 0-0.03 $\mathrm{m}$ depth (surface of the A horizon). and 3 , and Table 5. These equations were used to evaluate the traffic effects on the preconsolidation pressure.

According to the criteria in Figure 1, in 1996 at 0-0.03 m depth, the operations with Feller Büncher, Harvester and Forwarder presented 11, 44 and 63\%, respectively for the Udult, and 7, 11 and $26 \%$, respectively for the Aquox, of soil samples with preconsolidation pressure values determined after the traffic, in the region with additional soil compaction (Table 6). These results, associated with the values of the initial bulk density (Table 3), indicated that operations done with the Forwarder caused greater soil compaction than those with the Feller Büncher and Harvester.

Although operations performed with the Forwarder were considered critical, one might consider that the

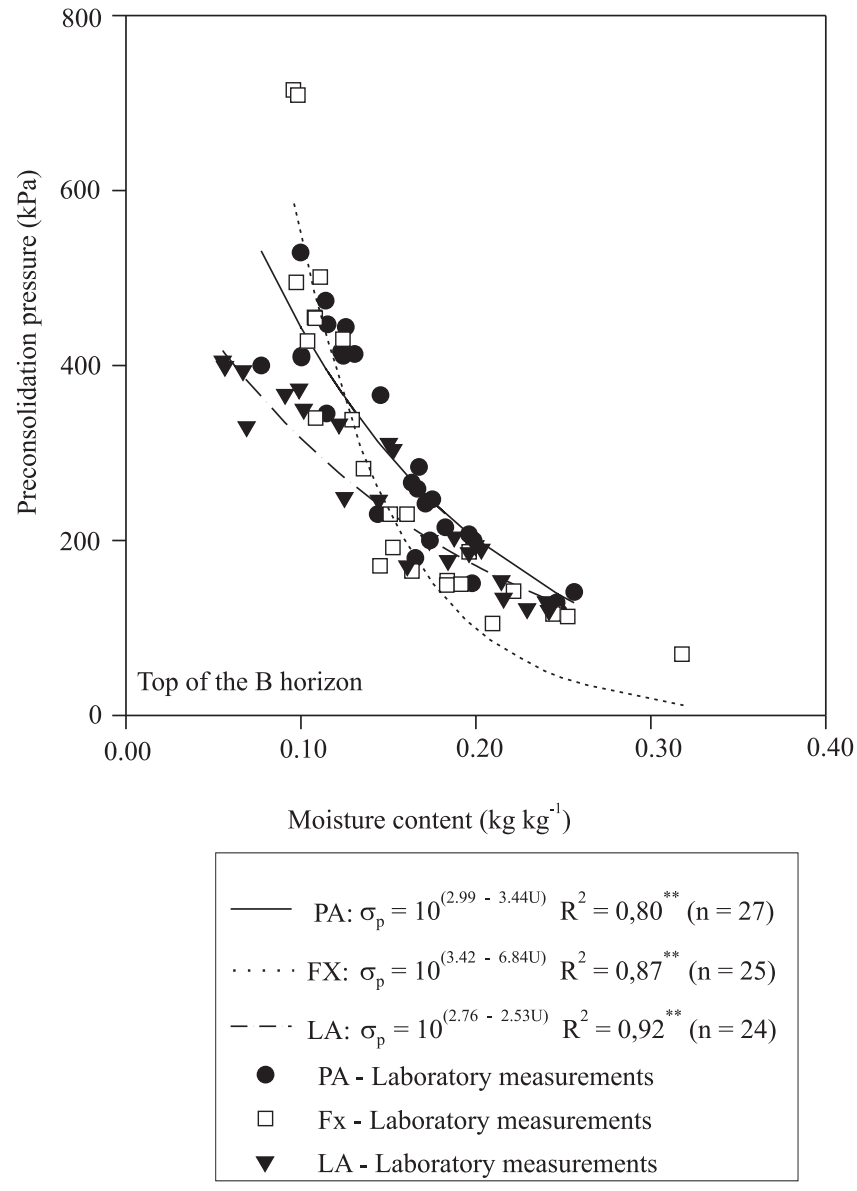

Figure 3. Bearing capacity model of the Udult (PA) and Aquox (FX), under eucalyptus plantation at $0.35-0.38 \mathrm{~m}$ depth (top of the B horizon), and at $0.15-0.18 \mathrm{~m}$ depth (top of the B horizon) of the Udox (LA). 
traffic with this machine is spatially restricted, avoiding, therefore, the dissemination of soil compaction in the whole area (Dias Junior et al., 1999).

The preconsolidation pressure values measured from 1996 to 2004 in the Udult and Aquox, and from 1998 to 2004 in the Udox, before harvest operations, decreased in the region with additional soil compaction, and increased in the region where the preconsolidation pressure values were smaller than the higher limit of the

Table 5. Coefficients a and $b$ of the equation $\sigma_{p}=10^{(a+b U)}$, standard error and $\mathrm{p}$ values.

\begin{tabular}{|c|c|c|c|}
\hline Coefficient & Value & Standard error & $\mathrm{p}$ \\
\hline & \multicolumn{3}{|c|}{ PA, FX, LA at $0-0.03 \mathrm{~m}$ depth (surface of A horizon) $(\mathrm{n}=76)$} \\
\hline $\mathrm{a}$ & 2.88 & 0.0235 & $<0.0001$ \\
\hline \multirow[t]{2}{*}{$\mathrm{b}$} & -3.95 & 0.2126 & $<0.0001$ \\
\hline & \multicolumn{3}{|c|}{ PA at $0.35-0.38 \mathrm{~m}$ depth (top of B horizon) $(\mathrm{n}=27)$} \\
\hline $\mathrm{a}$ & 2.99 & 0.0532 & $<0.0001$ \\
\hline \multirow[t]{2}{*}{$\mathrm{b}$} & -3.44 & 0.3969 & $<0.0001$ \\
\hline & \multicolumn{3}{|c|}{ FX at $0.35-0.38 \mathrm{~m}$ depth (top of B horizon) $(\mathrm{n}=25)$} \\
\hline $\mathrm{a}$ & 3.42 & 0.0898 & $<0.0001$ \\
\hline \multirow[t]{2}{*}{$\mathrm{b}$} & -6.84 & 0.0772 & $<0.0001$ \\
\hline & \multicolumn{3}{|c|}{ LA at $0.15-0.18 \mathrm{~m}$ depth (top of the $\mathrm{B}$ horizon) $(\mathrm{n}=24)$} \\
\hline $\mathrm{a}$ & 2.76 & 0.0269 & $<0.0001$ \\
\hline $\mathrm{b}$ & -2.53 & 0.0212 & $<0.0001$ \\
\hline
\end{tabular}

PA: Udult; FX: Aquox; LA: Udox. confidence interval (Table 6), indicating a natural recovery of the soil structure (Dias Junior et al., 2005).

The natural recovery of the soil structure was more evident at the surface of the A horizon. However, this interpretation was applied for the regarded soil depths of $0.0-0.03$ and $0.35-0.38 \mathrm{~m}$, which are very near to the soil surface. In deeper layers, the crushing of aggregates by compaction can lead to a reduction of the preconsolidation pressure, which cannot be regarded as a structural recovering process (Silva, 2006).

The percentage of soil samples in the region with additional soil compaction measured in 1996, for the Udult and Aquox, and 1998 for the Udox, indicated that the Udult was the soil class more susceptible to soil compaction, followed by the Aquox and Udox (Table 6). Despite this susceptibility, Udult was more efficient in its structure regeneration than the Aquox.

The measurements made from 1996 to 2004, before harvest operations, indicated a high percentage of soil samples with preconsolidation pressure values in the region where these values were within the limits of the confidence intervals (Table 6), mainly in the Udult and

Table 6. Classification of the soil samples according to Figure 1, using the preconsolidation pressure values determined after harvest operations in the Udult (PA) and in the Aquox (FX), at 0.0-0.03 m (surface of the A horizon) and 0.35-0.38 $\mathrm{m}$ depths, and at $0-0.03 \mathrm{~m}$ (surface of the A horizon) and 0.15-0.18 $\mathrm{m}$ (top of the B horizon) depths in the Udox (LA).

\begin{tabular}{|c|c|c|c|c|c|c|c|c|}
\hline \multirow[t]{3}{*}{ Soil class } & \multicolumn{8}{|c|}{ Traffic line } \\
\hline & \multirow{2}{*}{$\begin{array}{c}\text { Feller } \\
1996\end{array}$} & \multirow{2}{*}{$\begin{array}{c}\text { Harvester } \\
1996\end{array}$} & \multicolumn{6}{|c|}{ Forwarder } \\
\hline & & & 1996 & 1998 & 2000 & 2002 & 2004 (before harvest) & 2004 (after harvest) \\
\hline & \multicolumn{8}{|c|}{$\begin{array}{l}\text { Surface of the A horizon } \\
\end{array}$} \\
\hline PA & 11 & 44 & 63 & 22 & 11 & 4 & 7 & 67 \\
\hline FX & 7 & 11 & 26 & 30 & 11 & 11 & 7 & 30 \\
\hline LA & $-(1)$ & - & - & 16 & 16 & 0 & 0 & 15 \\
\hline & \multicolumn{8}{|c|}{ Percentage of soil samples with $\sigma_{\mathrm{p}}$ within the limits of the confidence interval } \\
\hline PA & 78 & 56 & 37 & 74 & 85 & 92 & 93 & 33 \\
\hline FX & 82 & 74 & 70 & 70 & 74 & 74 & 82 & 70 \\
\hline LA & - & - & - & 28 & 38 & 19 & 37 & 85 \\
\hline & \multicolumn{8}{|c|}{ Percentage of soil samples with $\sigma_{\mathrm{p}}$ below the lower limit of the confidence interval } \\
\hline PA & 11 & 0 & 0 & 4 & 4 & 4 & 0 & 0 \\
\hline FX & 11 & 15 & 4 & 0 & 15 & 15 & 11 & 0 \\
\hline \multirow[t]{3}{*}{ LA } & - & - & - & 56 & 46 & 81 & 63 & 0 \\
\hline & \multicolumn{8}{|c|}{ Top of the B horizon } \\
\hline & \multicolumn{8}{|c|}{ Percentage of soil samples with $\sigma_{\mathrm{p}}$ above the higher limit of the confidence interval } \\
\hline PA & 0 & 0 & 4 & 11 & 0 & 0 & 0 & 7 \\
\hline FX & 7 & 4 & 7 & 7 & 7 & 7 & 4 & 15 \\
\hline LA & - & - & - & 62 & 54 & 8 & 8 & 41 \\
\hline & \multicolumn{8}{|c|}{ Percentage of soil samples with $\sigma_{p}$ within limits of the confidence interval } \\
\hline PA & 67 & 89 & 96 & 85 & 74 & 85 & 89 & 89 \\
\hline FX & 78 & 81 & 89 & 89 & 78 & 82 & 85 & 81 \\
\hline LA & - & - & - & 21 & 15 & 44 & 33 & 59 \\
\hline \multicolumn{9}{|c|}{ Percentage of soil samples with $\sigma_{\mathrm{p}}$ below the lower limit of the confidence interval } \\
\hline PA & 33 & 11 & 0 & 4 & 26 & 15 & 11 & 4 \\
\hline FX & 15 & 15 & 4 & 4 & 15 & 11 & 11 & 4 \\
\hline LA & - & - & - & 17 & 31 & 48 & 59 & 0 \\
\hline
\end{tabular}

(1) Not determined. 
Aquox. This region is important because it shows the possibility of soil compaction to occur in the next harvest operations, if the soil bearing capacity and the appropriated soil moisture content are not considered in the operations planning.

The percentage of soil samples at the surface of A horizon, with preconsolidation pressure values in the region with additional soil compaction, increased from $7 \%$ in 2004, before harvest operations, to $67 \%$ in 2004 after harvest operations in the Udult, from 7 to $30 \%$ in the Aquox, and from 0 to $15 \%$ in the Udox.

At the top of the B horizon, the percentage of soil samples with additional soil compaction increased from $0 \%$ in 2004, before harvest operations, to $7 \%$ in 2004, after harvest operations in the Udult, from 4 to $15 \%$ in the Aquox, and from 8 to $41 \%$ in the Udox. Those percentages were lightly larger, for the $\mathrm{A}$ and $\mathrm{B}$ horizons of the Udult and Aquox, than the percentage of soil samples with preconsolidation pressure values, in the region with additional soil compaction observed in 1996.

For the Udox, in both horizons, the percentages of soil samples with preconsolidation pressure, in the region with additional soil compaction, were smaller than those observed in 1998. These observations indicated a sustainable forest exploration through the years (Dias Junior et al., 2005).

The probable reasons of the soil structural regeneration under eucalyptus plantation are attributed to the following aspects. In the A horizon, the vertical pores preserved in the minimum tillage increase water infiltration and, due to the addition of organic matter with its decomposition products, propitiate higher aggregation, resulting in an improvement of soil structure. Also, the macro and mesofauna play an important role in soil structure development (Larson \& Allmaras, 1971; Larink $\&$ Schrader, 2000). In depth, the subsoiling which destroys the dense layer starting from the top of the B horizon propitiates a larger penetration facility, with consequent formation of an adequate architecture of eucalyptus root system, minimizing, therefore, the hydric stress and warranting a good productivity at the end of the cycle. Thus, decayed root channels from deep-rooted perennial are important in water transmission in some soils, as well as the removal of water by the roots, which may cause a greater shrinkage near the roots interface. All these heterogeneities induced by roots are likely to cause aggregation of the soil (Larson \& Allmaras, 1971).

\section{Conclusions}

1. The operations performed with the Forwarder produce greater soil compaction than the Feller Büncher and Harvester.

2. The preconsolidation pressure values measured from 1996 to 2004, before harvest operations, indicate a natural recovery of the soil structure in the studied soil classes.

3. The percentage of soil samples with preconsolidation pressure values determined after the harvest operations done in 1996, 1998 and in 2004, indicates a sustainable forest exploration in this period.

\section{Acknowledgements}

To Conselho Nacional de Desenvolvimento Científico e Tecnológico (CNPq), for the productivity research grant; to Aracruz Celulose S.A., for the financing support of this research.

\section{References}

ARVIDSSON, J.; SJÖBERG, E.; AKKER, J.J.H. van den. Subsoil compaction by heavy sugarbeet harvesters in Southern Sweden: III. Risk assessment using a soil water model. Soil and Tillage Research, v.73, p.77-87, 2003.

BARBOSA, J.A.; VIEIRA, L.B.; DIAS, G.P.; DIAS JUNIOR, M.S. Desempenho operacional de um trator equipado alternadamente com pneus radiais e diagonais. Engenharia Agrícola, v.25, p.474-480, 2005.

BARBOSA, J.A.; VIEIRA, L.B.; DIAS JUNIOR, M.S.; DIAS, G.P. Efeito do tráfego de um trator agrícola na pressão de preconsolidação de um Argissolo Vermelho-Amarelo. Scientia Agraria Paranaensis, v.2, p.17-27, 2003.

BOWLES, J.E. Engineering properties of soils and their measurements. $3^{\text {rd }}$ ed. New York: McGraw-Hill, 1986. 218p.

BRAUNACK, M.V.; McPHEE, J.E.; REID, D.J. Controlled traffic to increase productivity of irrigated row crops in the semi-arid tropic. Australian Journal of Experimental Agriculture, v.35, p.503513, 1995.

DEFOSSEZ, P.; RICHARD, G. Models of soil compaction due to traffic and their evaluation. Soil and Tillage Research, v.67, p.4164, 2002.

DIAS JUNIOR, M.S. A soil mechanics approach study to soil compaction. In: ACHYUTHAN, H. (Ed.). Soil and soil physics in continental environment. Chenna: Allied Pub. Private, 2003. p.179-199.

DIAS JUNIOR, M.S. Compactação do solo. In: NOVAIS, R.F.; ALVAREZ VENEGAS, V.H.; SCHAEFER, C.E.G.R. (Ed.). Tópicos em ciência do solo. Viçosa: SBCS, 2000. p.55-94. 
DIAS JUNIOR, M.S.; FERREIRA, M.M.; FONSECA, S.; SILVA, A.R.; FERREIRA, D.F. Avaliação quantitativa da sustentabilidade estrutural dos solos em sistemas florestais na região de Aracruz - ES. Revista Árvore, v.23, p.371-380, 1999.

DIAS JUNIOR, M.S.; LEITE, F.P.; LASMAR JUNIOR, E.; ARAÚJO JUNIOR, C.F. Traffic effects on the soil preconsolidation pressure due to eucalyptus harvest operations. Scientia Agricola, v.62, p.248-255, 2005.

DIAS JUNIOR, M.S.; LEITE, F.P.; WINTER, M.E.; PIRES, J.V.G Avaliação quantitativa da sustentabilidade estrutural de um Latossolo Amarelo cultivado com eucalipto na região de Peçanha - MG. Revista Árvore, v.27, p.343-349, 2003.

DIAS JUNIOR, M.S.; PIERCE, F.J. A simple procedure for estimating preconsolidation pressure from soil compression curves. Soil Technology, v.8, p.139-151, 1995.

DIAS JUNIOR, M.S.; PIERCE, F.J. O processo de compactação do solo e sua modelagem: revisão de literatura. Revista Brasileira de Ciência do Solo, v.20, p.175-182, 1996.

EMBRAPA. Centro Nacional de Pesquisa de Solos (Rio de Janeiro, RJ). Sistema brasileiro de classificação de solos. Brasília: Embrapa-CNPS/Embrapa-SPI, 1999. 412p.

GARDNER, W.H. Water content. In: KLUTE, A. (Ed.). Methods of soil analysis. $2^{\text {nd }}$ ed. Madison: American Society of Agronomy, 1986. v.1, p.493-544.

HAMZA, M.A.; ANDERSON, W.K. Soil compaction in cropping systems: a review of the nature, causes and possible solutions. Soil and Tillage Research, v.82, p.121-145, 2005.

HOLTZ, R.D.; KOVACS, W.D. An introduction to geotechnical engineering. Englewood Cliffs: Prentice-Hall, 1981.733p.

HORN, R.; VOSSBRINK, J.; BECKER, S. Modern forestry vehicles and their impacts on soil physical properties. Soil and Tillage Research, v.79, p.207-219, 2004.

KONDO, M.K.; DIAS JUNIOR, M.S. Compressibilidade de três Latossolos em função da umidade e uso. Revista Brasileira de Ciência do Solo, v.23, p.211-218, 1999.
LARINK, O.; SCHRADER, St. Rehabilitation of degraded compacted soil by earthworms. In: HORN, R.; AKKER, J.J.H. van den; ARVIDSSON, J. (Ed.). Subsoil compaction: distribution, process and consequences. Reiskirchen: Catena Verlag GMBH, 2000. p.284-294. (Advances in Geoecology, 32).

LARSON, W.E.; ALLMARAS, R.R. Management factors and natural forces as related to compaction. In: BARNES, K.K.; CARLETON, W.M.; TAYLOR, H.M.; THROCKMORTON, R.I.; VANDEN BERG, G.E. (Ed.). Compaction of agricultural soils. St. Joseph: ASAE, 1971. p.367-427.

OLIVEIRA, G.C.; DIAS JUNIOR, M.S.; CURI, N.; RESCK, D.V.S. Compressibilidade de um Latossolo Vermelho argiloso de acordo com a tensão de água no solo, uso e manejo. Revista Brasileira de Ciência do Solo, v.27, p.773-781, 2003.

RAPER, R.L. Agricultural traffic impacts on soil. Journal of Terramechanics, v.42, p.259-280, 2005.

SILVA, A.R. Modelagem e quantificação da compactação de Latossolos cultivados com eucalipto. 2006. 85p. Tese (Doutorado) - Universidade Federal de Lavras, Lavras.

SILVA, A.R.; DIAS JUNIOR, M.S.; GUIMARÃES, P.T.G.; ARAUJO JUNIOR, C.F. Modelagem da capacidade de suporte de carga e quantificação dos efeitos das operações mecanizadas em um Latossolo Amarelo cultivado com cafeeiros. Revista Brasileira de Ciência do Solo, v.30, p.207-216, 2006.

SILVA, R.B.; DIAS JUNIOR, M.S.; SILVA, F.A.M.; FOLLE, S.M. $\mathrm{O}$ tráfego de máquinas agrícolas e as propriedades físicas, hídricas e mecânicas de um Latossolo dos Cerrados. Revista Brasileira de Ciência do Solo, v.27, p.973-983, 2003.

SNEDECOR, G.W.; COCHRAN, W.G. Statistical methods. $8^{\text {th }}$ ed. Ames: Iowa State University Press, 1989. 503p.

SOIL taxonomy: a basic system of soil classification for making and interpreting soil surveys. $2^{\text {nd }}$ ed. Washington: USDA, Natural Resources Conservation Service, 1999. 869p.

TAYLOR, D.W. Fundamentals of soil mechanics. New York: Wiley, 1948. 700p.

Received on March 17, 2006 and accepted on October 11, 2006 